\title{
Global transcriptomic response of Leptospira interrogans serovar Copenhageni upon exposure to serum
}

Kanitha Patarakul', Miranda Lo ${ }^{2,3}$, Ben Adler ${ }^{2,3^{*}}$

\begin{abstract}
Background: Leptospirosis is a zoonosis of worldwide distribution caused by infection with pathogenic serovars of Leptospira spp. The most common species, L. interrogans, can survive in the environment for lengthy periods of time in between infection of mammalian hosts. Transmission of pathogenic Leptospira to humans mostly occurs through abraded skin or mucosal surfaces after direct or indirect contact with infected animals or contaminated soil or water. The spirochete then spreads hematogenously, resulting in multi-organ failure and death in severe cases. Previous DNA microarray studies have identified differentially expressed genes required for adaptation to temperature and osmolarity conditions inside the host compared to those of the environment.

Results: In order to identify genes involved in survival in the early spirochetemic phase of infection, we performed a transcriptional analysis of $L$. interrogans serovar Copenhageni upon exposure to serum in comparison with EMJH medium. One hundred and sixty-eight genes were found to be differentially expressed, of which 55 were upregulated and 113 were down-regulated. Genes of known or predicted function accounted for 54.5 and $45.1 \%$ of up- and down-regulated genes, respectively. Most of the differentially expressed genes were predicted to be involved in transcriptional regulation, translational process, two-component signal transduction systems, cell or membrane biogenesis, and metabolic pathways.

Conclusions: Our study showed global transcriptional changes of pathogenic Leptospira upon exposure to serum, representing a specific host environmental cue present in the bloodstream. The presence of serum led to a distinct pattern of gene expression in comparison to those of previous single-stimulus microarray studies on the effect of temperature and osmolarity upshift. The results provide insights into the pathogenesis of leptospirosis during the early bacteremic phase of infection.
\end{abstract}

\section{Background}

Leptospira interrogans is the most common etiologic agent of severe leptospirosis, a zoonotic disease with worldwide distribution [1-3]. Leptospires have been serologically classified based on antigenic determinants into more than 230 serovars. With more recent genetic classification based on DNA relatedness, Leptospira has been classified into at least 17 species [1,4-6]. However, no correlation exists between serological and genetic classification. Many species of animals, both domestic and wild, serve as reservoir hosts, resulting in the global spread of the disease. Humans are accidental hosts, with

\footnotetext{
* Correspondence: ben.adler@med.monash.edu.au

${ }^{2}$ ARC Centre of Excellence in Structural and Functional Microbial Genomics, Monash University, Clayton, Victoria 3800, Australia
}

transmission occurring via direct or indirect contact with the urine of infected animals. Pathogenic Leptospira can survive for prolonged periods of time in the environment [7]. After gaining entry through skin abrasions or mucous membranes, the spirochete spreads hematogenously to multiple target organs such as the kidneys, liver, and lung, resulting in a wide spectrum of clinical manifestations $[1,3]$. Therefore, adaptation to various environmental cues outside and within the hosts and the ability to survive in the bloodstream contribute to the ability of leptospires to cause disease.

The responses of leptospires at transcriptional and translational levels to changes in various environmental factors such as temperature, osmolarity, and iron availability have been reported previously [8-13]. Proteins such as

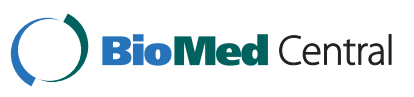


Qlp42, Hsp15, LigA, LigB, Sph2, and Lsa21 are up-regulated in response to physiologic temperature or osmolarity [12,14-17]. In contrast, LipL36 is down-regulated at $37^{\circ} \mathrm{C}$ and during mammalian infection $[8,18]$. Previous studies demonstrated the in vivo expression of several outer membrane proteins, based on the presence of antibodies against these proteins in immune sera or detection of proteins in host tissues infected with pathogenic Leptospira [17,19-27]. These proteins, which are expressed in vivo or at physiologic conditions, therefore constitute potential virulence-associated factors required for host interaction or survival of Leptospira in infected hosts.

DNA microarrays have been used to study genomewide differential gene expression of bacteria during infection and upon exposure to various stimuli related to in vivo conditions [28-32]. Based on available wholegenome sequences of Leptospira [33,34], microarray techniques have been utilized to identify a range of genes that are responsive to changes in temperature and/or osmolarity, corresponding to the shift from environmental to physiological conditions $[10,11,13]$. These microarray studies have usually involved a single stimulus, such as temperature or osmolarity upshift, each resulting in differing expression profiles. However, L. interrogans within the mammalian host simultaneously encounters multiple signals that are different from environmental conditions. In the early course of infection, leptospires have to survive and spread in the bloodstream before causing damage to target organs. Blood or serum contains physical, biochemical, and biological properties that are different from those of the in vitro environment, such as complement, $\mathrm{pH}$, osmolarity, iron availability, electrolyte concentration, and various serum proteins. Therefore, regulation of gene expression during the spirochetemic phase is the result of integrated and complex stimuli. However, leptospiral genes differentially expressed during the period of bacteremic phase have never been characterized.

In this study, we employed DNA microarray analysis as a tool to identify genes that are differentially expressed in the presence of serum, as these genes may be important in enabling pathogenic Leptospira to adapt to and survive in the host environment during the early bacteremic stage of infection. The results were compared to previous microarray data on the responses to changes in temperature and osmolarity $[10,11,13]$.

\section{Results and discussion}

\section{Serum bactericidal assay}

Serum complement plays a crucial role in the innate immune response against bacterial pathogens. To study differential gene expression of Leptospira in the presence of serum, we used commercial guinea pig serum with demonstrated complement leptospiricidal activity against $L$. biflexa. Pathogenic leptospires are resistant to the alternative pathway of complementmediated killing, in contrast to the non-pathogenic species, L. biflexa [35-38]. Guinea pigs are susceptible to acute infection with Leptospira and have been routinely used as an animal model for leptospirosis $[26,39,40]$. The same batch of guinea pig serum was used throughout this study to minimize variation between replicate samples.

It is known that pathogenic Leptospira may lose virulence after in vitro passage [41]. Therefore, serum leptospiricidal activity was tested against different pathogenic serovars available in our laboratory to determine their resistance to complement-mediated killing before use in microarray experiments. The maximum killing (>90\%) of non-pathogenic L. biflexa serovar Patoc was achieved after incubation with $50 \%$ guinea pig serum at $37^{\circ} \mathrm{C}$ for $30 \mathrm{~min}$ (data not shown). Hence, this condition was deemed to be sufficient for pathogenic leptospires to express genes required for survival in serum and was used for subsequent experiments. In this study, low-passage L. interrogans serovars Copenhageni and Manilae were shown to be resistant to complementmediated killing, with 95.5 and $97.3 \%$ retention of viability after incubation in serum, respectively, compared to 9\% viability of serovar Patoc. However, after incubation with heat-inactivated serum (HIS) the viability of $L$. biflexa was greater than 95\%, consistent with the killing effect of serum being due to complement activity. Accordingly, serovar Copenhageni was used in subsequent microarray experiments, since microarray slides were constructed based on the combined complete genome sequences of serovars Lai and Copenhageni available in the database [11].

\section{Global transcriptomic changes of pathogenic Leptospira after serum exposure}

Low-passage L. interrogans serovar Copenhageni was incubated with $50 \%$ guinea pig serum at $37^{\circ} \mathrm{C}$ for 30 min to simulate in vivo conditions encountered upon entry into the host. Comparisons were made with leptospires shifted to $37^{\circ} \mathrm{C}$ in EMJH medium to exclude the effect of temperature shift, which has previously been reported $[10,11]$.

Overall, 168 genes (4.5\% of the genome) were considered to be differentially expressed at a statistically significant level upon serum exposure, i.e. at least 1.5-fold up- or down-regulated with an adjusted $P$ value of less than 0.01 as determined by moderated $t$ test. Of these, 55 genes $(32.7 \%)$ were up-regulated and 113 genes (67.3\%) were down-regulated (Table 1). Genes of known or predicted function accounted for $54.5 \%$ (30 of 55 genes) and $45.1 \%$ (51 of 113 genes) of up- and downregulated genes, respectively. 
Table 1 Number of leptospiral genes differentially expressed in response to serum compared to EMJH medium

\begin{tabular}{|c|c|c|c|}
\hline \multirow[t]{2}{*}{ Genes } & \multicolumn{3}{|c|}{ No. of genes } \\
\hline & $\begin{array}{c}\text { Up- } \\
\text { regulated } \\
\left(\%{ }^{a}\right)\end{array}$ & $\begin{array}{l}\text { Down- } \\
\text { regulated }\left(\%^{\mathrm{a}}\right)\end{array}$ & $\begin{array}{l}\text { Total } \\
\left(\%^{\mathrm{b}}\right)\end{array}$ \\
\hline Known or predicted function & $30(54.5)$ & $51(45.1)$ & $\begin{array}{c}81 \\
(48.2)\end{array}$ \\
\hline $\begin{array}{l}\text { Unknown or poorly } \\
\text { characterized function }\end{array}$ & $25(45.5)$ & $62(54.9)$ & $\begin{array}{c}87 \\
(51.8)\end{array}$ \\
\hline Total & 55 & 113 & 168 \\
\hline
\end{tabular}

Differentially expressed genes were classified into functional categories based on clusters of orthologous groups (COGs). The majority of differentially expressed genes were of poorly characterized or unknown function (45.5 and $54.9 \%$ of up- and downregulated genes, respectively) (Figure 1A). In general, of the genes which were serum-inducible, those predicted to be involved in metabolism were overrepresented, followed by the cellular processes and signaling group (Figure 1A). However, down-regulated genes of known or predicted function were similarly distributed in three broad COG categories. Among genes of known or predicted function, the highest proportion of up-regulated genes $(10.9 \%)$ were those involved in cell wall and membrane biogenesis (COG category $\mathrm{M}$ ), whereas the largest group of down-regulated genes (11.5\%) belonged to COG category J (translation) (Figure $1 \mathrm{~B})$.

The most highly up-regulated gene (11.5-fold) was LIC13291, encoding a putative ankyrin repeat protein [Additional file 1]. Ankyrin repeat-containing proteins are ubiquitous proteins that play a role in protein-protein interactions [42-44]. LIC13291 is one of 12 predicted proteins with ankyrin repeat domains in $L$. interrogans [34]. However, protein interactions and partners of ankyrin repeat proteins in $L$. interrogans have not yet been characterized. It is possible that upregulation of this gene may be crucial for interactions of proteins involved in several functions such as intracellular signaling, nutrient acquisition, and transcriptional regulation to promote survival of Leptospira in response to stress conditions encountered in serum.

Interestingly, 11 of $55(20 \%)$ genes that were shown to be up-regulated in our study are unique to L. interrogans and are not present in the genome of the saprophytic L biflexa [45] [Additional file 1] which is susceptible to complement killing. These up-regulated unique $L$. interrogans genes may encode unique leptospiral virulence factors but their role, if any, in pathogenesis has yet to be determined.

The complete lists of significantly up- and down-regulated genes are shown as [Additional files 1 and 2] respectively. Differentially regulated genes of known or predicted function in each broad COG category (Tables 2 and 3) are discussed below.

\section{Information storage and processing}

Putative transcriptional regulators including a protein in the PadR family (encoded by LIC10378) were up-regulated in response to serum. PadR has been shown to be a transcriptional repressor of padA gene (encoding a phenolic acid decarboxylase) expression in response to phenolic acid stress in Lactobacillus plantarum [46,47]. However, the target of the leptospiral PadR homolog remains unknown. In the presence of serum, several subunits of $30 \mathrm{~S}$ and $50 \mathrm{~S}$ ribosomal proteins of Leptospira were repressed, possibly due to the shift of energy to produce other gene products that are needed for survival in serum. Reduction of ribosomal gene expression has also been found in organisms under various stress conditions such as Streptococcus pneumoniae isolated from infected blood [48], Campylobacter jejuni, Staphylococcus aureus, and Helicobacter pylori in response to acid shock [49-51], and E. coli under anaerobic and acidic conditions [52] and nitrogen and sulfur starvation [53].

\section{Cellular processes and signaling}

Serum exposure resulted in both up- and down-regulation of several genes involved in cellular processes and signal transduction. Different genes with the same predicted function, such as putative metallopeptidases (LIC11149 and LIC10271), sensor or receiver proteins of two-component response regulators (LIC20012, LIC11201, LIC12807, LIC12979 and LIC13289), and adenylate/guanylate cyclase (LIC10900 and LIC11095) were found to be regulated in opposite directions. LIC20012, an ortholog of hklep encoding a sensor kinase of the Hklep/Rrlep two-component system involved in heme biosynthesis in L. biflexa [54], was down-regulated. However, an ortholog of rrlep regulator (LIC20013) was not differentially expressed. Moreover, predicted anti-sigma factor (LIC13344) and anti-sigma factor antagonists (LIC10344 and LIC20108) were down-regulated in response to serum. Bacterial antisigma factors and anti-sigma factor antagonists are regulatory proteins that control sigma-factor functions in promoter recognition and initiation of RNA polymerase required for cell viability and stress response [55]. Antisigma factors bind to and block their cognate sigma factors, while anti-sigma factor antagonists (or anti-antisigma factors) form complexes with anti-sigma factors to inhibit their activity. These findings may be attributed to the fact that the genome of $L$. interrogans is predicted 


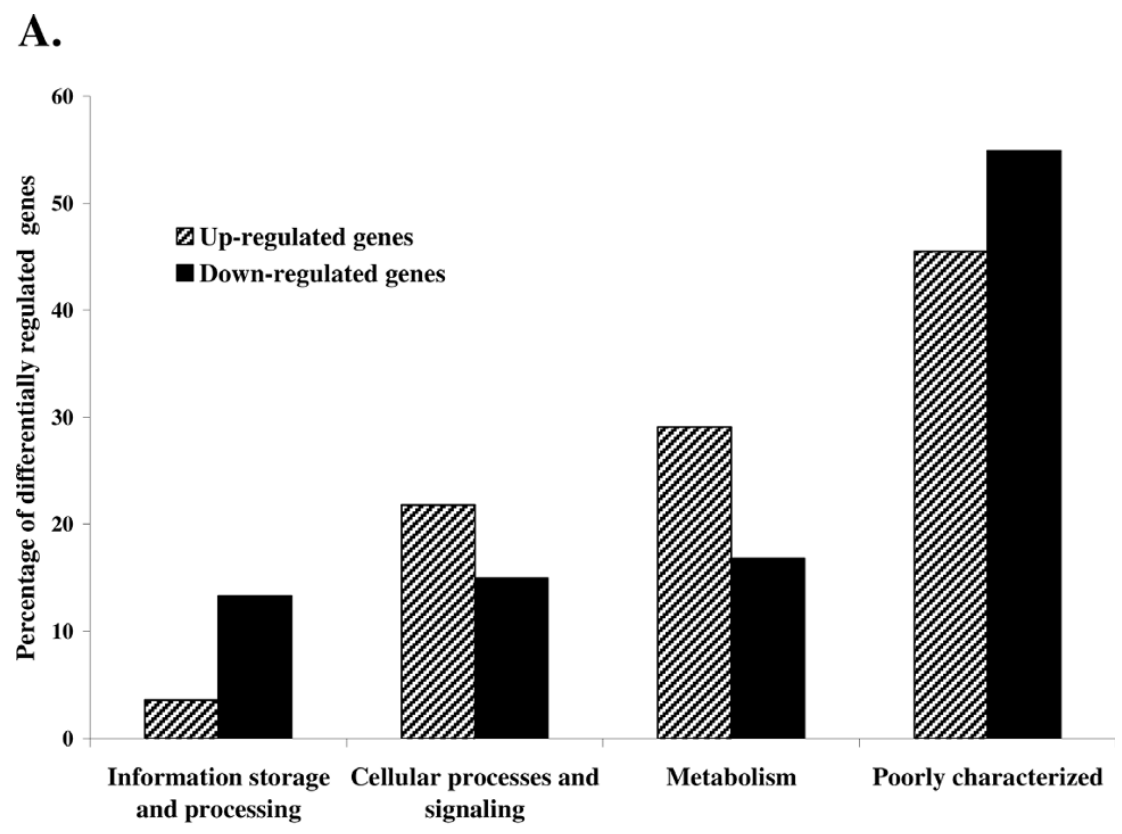

General COGs grouping

B.

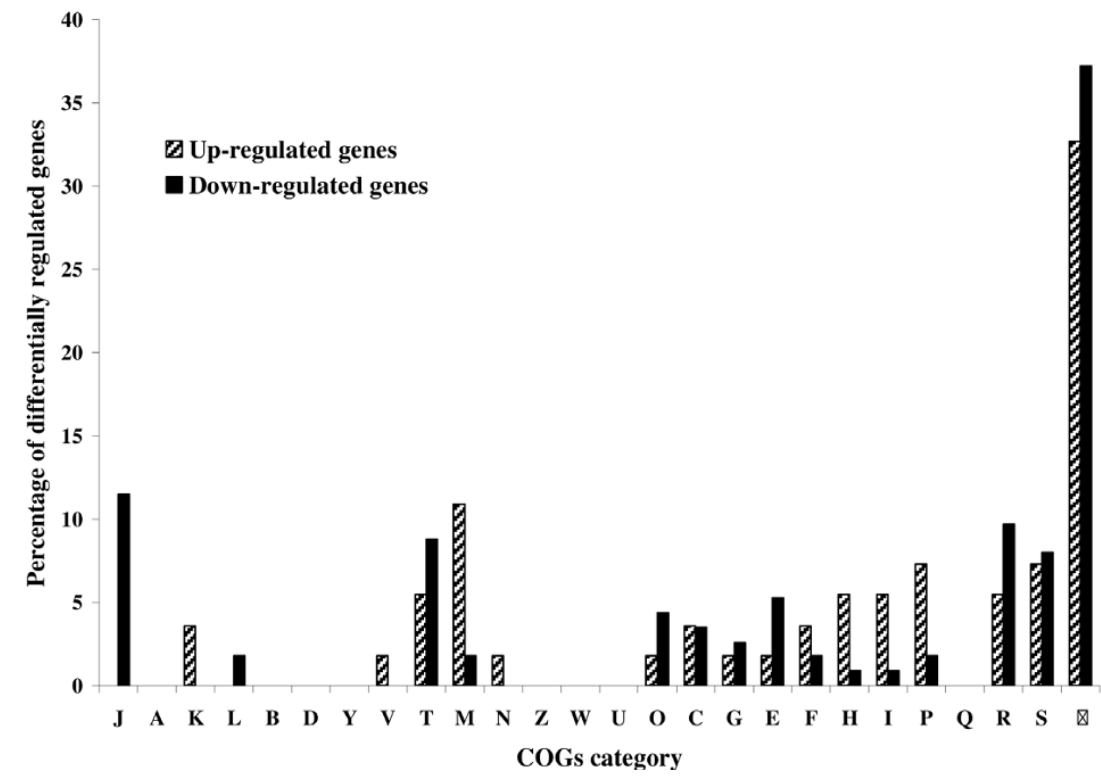

Figure 1 Percentage of up- and down-regulated genes of $L$. interrogans serovar Copenhageni in response to serum in each general COG grouping (A) and COG category (B). The percentage of differentially regulated genes was calculated by dividing number of genes upand down-regulated in each category by the total number of up- and down-regulated genes, respectively $\times 100$. The COG functional categories are as follows: information storage and processing (includes J, translation; A, RNA processing and modification; $K$, transcription; L, replication, recombination, and repair; B, chromatin structure and dynamics); cellular processes and signaling (includes D, cell cycle control, cell division, chromosome partitioning; $Y$, Nuclear structure; $V$, defense mechanisms; T, signal transduction mechanisms; $M$, cell wall, membrane, or envelope biogenesis; N, cell motility; Z, cytoskeleton; W, extracellular structures; $U$, intracellular trafficking, secretion, and vesicular trans- port; $\mathrm{O}$, posttranslational modification, protein turnover, chaperones); metabolism (includes $C$, energy production and conversion; $G$, carbohydrate transport and metabolism; E, amino acid transport and metabolism; F, nucleotide transport and metabolism; $H$, coenzyme transport and metabolism; I, lipid transport and metabolism; P, inorganic ion transport and metabolism; Q, secondary metabolite biosynthesis, transport, and catabolism); poorly characterized (includes R, general function prediction only; S, function unknown; and -, not in COGs). 
Table 2 Genes of known or predicted function which were up-regulated in response to serum

\begin{tabular}{|c|c|c|c|c|c|}
\hline Gene $I D^{a}$ and COG category & Gene & $\begin{array}{l}\text { Fold } \\
\text { ratio }\end{array}$ & Description of gene product & $\begin{array}{c}\text { Temperature } \\
\text { effect }^{b}\end{array}$ & $\begin{array}{c}\text { Osmolarity } \\
\text { effect }^{c}\end{array}$ \\
\hline \multicolumn{6}{|l|}{ Information storage and processing } \\
\hline \multicolumn{6}{|l|}{ - Transcription (K) } \\
\hline LIC11154 (LA2894) & & 1.70 & transcription regulator & - & - \\
\hline LIC10378 (LA0431) & & 1.54 & transcription regulator, PadR family & - & - \\
\hline \multicolumn{6}{|l|}{ Cellular process and signaling } \\
\hline \multicolumn{6}{|l|}{ - defense mechanisms ( $V$ ) } \\
\hline LIC12182 (LA1600) & & 1.58 & $\begin{array}{l}\text { ATP-binding protein of an } A B C \text { transporter } \\
\text { complex }\end{array}$ & - & - \\
\hline \multicolumn{6}{|l|}{ - signal transduction mechanisms ( $T$ ) } \\
\hline LIC12979 (LA0599) & & 2.49 & signal transduction protein & - & - \\
\hline LIC13289 (LA4127) & & 2.17 & $\begin{array}{l}\text { sensor histidine kinase of a two- component } \\
\text { response regulator }\end{array}$ & - & $\uparrow^{d}$ \\
\hline LIC10900 (LA3235) & & 1.72 & adenylate/guanylate cyclase & - & - \\
\hline \multicolumn{6}{|l|}{ - cell wall/membrane biogenesis (M) } \\
\hline LIC11149 (LA2901) & & 2.75 & metallopeptidase & - & - \\
\hline LIC12151 (LA1632) & & 2.45 & nucleoside-diphosphate sugar epimerase & - & - \\
\hline LIC10200 (LA0232) & & 2.17 & glycosyltransferase & - & - \\
\hline LIC10587 (LA3624) & & 2.07 & glycosyltransferase & - & - \\
\hline LIC11728 (LA2200) & & 2.01 & amidase & - & $\uparrow$ \\
\hline LIC13469 (LA4326) & $\operatorname{lpxD}$ & 1.65 & $\begin{array}{l}\text { UDP-3-O-(3-hydroxymyristoyl) glucosamine N- } \\
\text { acyltransferase }\end{array}$ & - & - \\
\hline \multicolumn{6}{|l|}{ - cell motility (N) } \\
\hline LIC10464 (LA3778) & $\operatorname{lig} B$ & 1.89 & LigB lipoprotein & $\uparrow$ & $\uparrow$ \\
\hline \multicolumn{6}{|l|}{$\begin{array}{l}\text { - posttranslational modification, protein } \\
\text { turnover, chaperones }(\mathrm{O})\end{array}$} \\
\hline LIC11657 (LA2280) & flis & 1.98 & endoflagellar biosynthesis chaperone & - & - \\
\hline \multicolumn{6}{|l|}{ Metabolism } \\
\hline \multicolumn{6}{|l|}{ - energy production and conversion (C) } \\
\hline LIC10090 (LA0102) & & 1.73 & $\begin{array}{l}\text { conserved hypothetical protein (FOG: } \\
\text { HEAT repeat) }\end{array}$ & - & - \\
\hline LIC20084 (LB107) & & 1.71 & $\begin{array}{l}\text { conserved hypothetical protein related to } \\
\text { ferredoxin oxidoreductase }\end{array}$ & - & - \\
\hline \multicolumn{6}{|l|}{ - carbohydrate transport and metabolism } \\
\hline (G) & & 1.77 & permease & - & $\uparrow$ \\
\hline \multicolumn{6}{|l|}{ LIC20149 (LB187) } \\
\hline - amino acid transport and metabolism (E) & & 1.69 & acetyltransferase & $\uparrow$ & - \\
\hline \multicolumn{6}{|l|}{ LIC12184 (LA1598) } \\
\hline - nucleotide transport and metabolism (F) & pyrD & 2.01 & dihydroorotate dehydrogenase & - & - \\
\hline LIC13433 (LA4290) & $d g t$ & 1.54 & deoxyguanosinetriphosphate & - & - \\
\hline LIC11663 (LA2274) & & & triphosphohydrolase & & \\
\hline - coenzyme transport and metabolism $(\mathrm{H})$ & & 1.82 & pyrimidine reductase & - & $\uparrow$ \\
\hline LIC13208 (LA4019) & & 1.58 & methylase/methyl transferase & - & - \\
\hline LIC20082 (LB105) & coaE & 1.55 & dephospho-CoA kinase & - & - \\
\hline \multicolumn{6}{|l|}{ LIC13085 (LA3863) } \\
\hline - lipid transport and metabolism (I) & & 2.59 & fatty acid desaturase & - & - \\
\hline LIC20052 (LB068) & $\operatorname{des} A$ & 2.59 & fatty acid desaturase & - & - \\
\hline LIC13053 (LA0502) & & 2.42 & enoyl-CoA hydratase & - & - \\
\hline LIC12629 (LA1032) & & & & & \\
\hline
\end{tabular}


Table 2: Genes of known or predicted function which were up-regulated in response to serum (Continued)

\begin{tabular}{|c|c|c|c|c|c|}
\hline - inorganic ion transport and metabolism & hemo & 2.47 & heme oxygenase & - & $\uparrow$ \\
\hline$(\mathrm{P})$ & & 1.82 & Reductase & - & - \\
\hline LIC20148 (LB186) & & 1.69 & cation transport ATPase, possibly copper & $\uparrow$ & - \\
\hline LIC13470 (LA4327) & & 1.51 & Bifunctional permease/carbonic anhydrase & - & - \\
\hline \multicolumn{6}{|l|}{ LIC12982 (LA0594) } \\
\hline LIC12992 (LA0579) & & & & & \\
\hline
\end{tabular}

to contain at least 79 genes encoding two-component sensor histidine kinase-response regulator proteins, 9 anti-sigma factors, and 19 anti-sigma factor antagonists required for response to various environmental signals [34]. Therefore, complex stimuli in serum encountered by Leptospira may simultaneously cause induction and repression of multiple genes involved in signal transduction networks and transcriptional regulation, possibly leading to expression of genes essential for survival under stress conditions and/or pathogenicity of leptospires inside the host. Detailed study of these individual genes is thus clearly warranted.

The gene encoding the LigB lipoprotein was up-regulated in response to serum. LigB interacts with fibronectin and may serve as an adhesin by binding to host extracellular matrix during the early stages of infection [56-58]. However, recent studies with site-directed mutagenesis of $\operatorname{lig} B$ did not show attenuation of a $\operatorname{lig} B$ mutant in the hamster model of leptospirosis [59]. This finding does not exclude the role of LigB as a virulence determinant, since previous studies have shown redundancy in extracellular matrix-binding function of leptospiral proteins including a $36-\mathrm{kDa}$ fibronectin-binding protein [60], Lsa24 (also known as LfhA and LenA) [61,62], LigA [16], Len proteins [62], LipL32 [63], and Lsa21 [17]. Our finding is therefore consistent with the hypothesis that LigB plays a role in virulence, but is not essential.

The $l p x D$ (LIC13469) gene encoding UDP-3-O-(3hydroxymyristoyl) glucosamine $\mathrm{N}$-acyltransferase, which catalyzes the third step of lipid A biosynthesis [64], was up-regulated in response to serum. Lipid A modification was previously shown to affect interaction between Gram-negative bacteria and their environment and to confer virulence in some bacteria [65]. In H. pylori, $l p x D$ was induced after adhesion to AGS gastric cancer cells [66]. Hence, the differential regulation of $\operatorname{lp} x D$ might allow L. interrogans to modify its lipid A, resulting in alteration of the physical properties of the outer membrane in response to changes in environmental conditions. Notably, the $l p x D$ is not arranged in an operon in Leptospira, and its differential regulation may thus represent a mechanism for varying LPS expression.

Expression of genes encoding proteins predicted to be involved in the heat shock response, such as $\operatorname{clp} A$ (LIC12017) encoding the ATP-dependent proteolytic subunit of Clp endopeptidase, and htpG (LIC20044), encoding the molecular chaperone Hsp90, was downregulated in response to serum. The result is not surprising since our experiment did not generate a temperature shift between experimental and control samples, i.e. leptospires were incubated in serum and EMJH medium at the same temperature. The expression of these genes may be affected by signals other than temperature. However, further investigation is required to characterize stress signals in serum that cause downregulation of these genes. Additionally, down-regulation of genes encoding proteins predicted to be involved in oxidative stress, namely btuE (LIC13442) encoding glutathione peroxidase, $t p x$ (LIC12765) encoding peroxiredoxin, bcp (LIC20093) encoding bacterioferritin comigratory protein, and $u b i G$ (LIC10737) encoding the last enzyme in ubiquinone biosynthetic pathway [67-69], was observed in serum-incubated leptospires, consistent with an absence of oxidative stress in serum without any host phagocytic or other cells.

\section{Metabolism}

To survive in the bloodstream, pathogens need to adjust their metabolism in response to nutrient limitations. In our study, several leptospiral genes involved in metabolic processes were up- or down-regulated, depending on available sources of nutrients and energy in serum compared to those in EMJH medium. The gene hemO (LIC20148) encoding heme oxygenase was induced 2.47fold in response to serum. Heme is an essential in vivo source of iron required for growth and biological processes, including electron transfer reactions of leptospires during infection [70]. Bacterial heme oxygenases are enzymes that release $\mathrm{Fe}^{2+}$ from heme by cleaving its tetrapyrrole ring in the presence of oxygen [71]. Previous studies have demonstrated that a transposon mutant in hemO of pathogenic Leptospira could not 
Table 3 Genes of known or predicted function which were down-regulated in response to serum

\begin{tabular}{|c|c|c|c|c|c|}
\hline Gene ID and COG category & Gene & $\begin{array}{l}\text { Fold } \\
\text { ratio }\end{array}$ & Description of gene product & $\begin{array}{c}\text { Temperature } \\
\text { effect }^{b}\end{array}$ & $\begin{array}{c}\text { Osmolarity } \\
\text { effect }^{c}\end{array}$ \\
\hline \multicolumn{6}{|l|}{ Information storage and processing } \\
\hline \multicolumn{6}{|l|}{$\begin{array}{l}\text { - translation, ribosomal structure and } \\
\text { biogenesis }(J)\end{array}$} \\
\hline LIC12111 (LA1677) & $r p s R$ & -2.64 & $30 S$ ribosomal protein $\mathrm{S} 18$ & - & - \\
\hline LIC12865 (LA0747) & rpmC & -1.91 & $50 S$ ribosomal protein L29 & - & - \\
\hline LIC12637 (LA1020) & rpmE & -1.88 & $50 S$ ribosomal protein L31 & - & - \\
\hline LIC10750 (LA3423) & $r p / A$ & -1.82 & $50 S$ ribosomal protein $\mathrm{L} 1$ & - & - \\
\hline LIC12862 (LA0750) & $r p / X$ & -1.75 & $50 S$ ribosomal protein L24 & - & - \\
\hline LIC12113 (LA1675) & rpsF & -1.70 & 305 ribosomal protein $\mathrm{S} 6$ & - & - \\
\hline LIC12845 (LA0766) & $r p / Q$ & -1.65 & $50 S$ ribosomal protein L17 & - & - \\
\hline LIC12774 (LA0851) & rpmA & -1.61 & $50 S$ ribosomal protein $\mathrm{L} 27$ & - & - \\
\hline LIC12860 (LA0752) & $\operatorname{rps} N$ & -1.59 & 30 S ribosomal protein $\mathrm{S} 14$ & - & - \\
\hline LIC12871 (LA0741) & $r p / W$ & -1.55 & $50 S$ ribosomal protein $L 23$ & - & - \\
\hline LIC10756 (LA3416) & $\operatorname{rps} G$ & -1.54 & $30 S$ ribosomal protein $\mathrm{S} 7$ & - & - \\
\hline LIC10751 (LA3422) & $r p / J$ & -1.54 & $50 S$ ribosomal protein L10 & - & - \\
\hline LIC12855 (LA0757) & rpmD & -1.52 & $50 S$ ribosomal protein $L 30$ & - & - \\
\hline \multicolumn{6}{|c|}{ - replication, recombination and repair $(\mathrm{L})$} \\
\hline LIC20098 (LB122) & & -2.80 & XerD related protein (integrase family) & - & $\downarrow^{d}$ \\
\hline LIC12112 (LA1676) & ssb & -1.70 & single-stranded DNA-binding protein & - & - \\
\hline
\end{tabular}

Cellular process and signaling

- signal transduction mechanisms (T)

LIC20012 (LB014)

LIC11201 (LA2829)

LIC12762 (LA0866)

LIC12807 (LA0816)

LIC10344 (LA0395)

LIC13344 (LA4189)

LIC20108 (LB136)

LIC20025 (LB031)

LIC11095 (LA2968)

LIC12357 (LA1378)

- cell wall/membrane biogenesis (M)

LIC10271 (LA0312)

LIC12621 (LA1044)

- posttranslational modification, protein turnover, chaperones (O)
LIC12017 (LA1879)
LIC12765 (LA0862)
LIC13442 (LA4299)
LIC20044 (LB058)
LIC20093 (LB117)

Metabolism

- energy production and conversion (C)

LIC12002 (LA1897)

LIC12476 (LA1222) sensor protein of a two-component response regulator

receiver component of a twocomponent response regulator signal transduction protein receiver component of a twocomponent response regulator anti-sigma factor antagonist anti-sigma regulatory factor (Ser/Thr protein kinase) anti-sigma factor antagonist cyclic nucleotide-binding protein adenylate/guanylate cyclase membrane GTPase

metallopeptidase, M23/M27 family conserved hypothetical protein

endopeptidase Clp peroxiredoxin glutathione peroxidase HSP9O bacterioferritin comigratory protein
sdhA -1.72 succinate dehydrogenase/fumarate reductase subunit A

aceF $\quad-1.63$ dihydrolipoyllysine-residue acetyl transferase and succinyltransferase 
Table 3: Genes of known or predicted function which were down-regulated in response to serum (Continued)

\begin{tabular}{|c|c|c|c|c|c|}
\hline LIC12217 (LA1553) & petE & -1.62 & plastocyanin & - & $\downarrow$ \\
\hline LIC12829 (LA0790) & $g / t A$ & -1.53 & citrate (Si)-synthase & - & - \\
\hline \multicolumn{6}{|l|}{ - carbohydrate transport and metabolism } \\
\hline (G) & & -1.82 & phosphonomutase & - & $\downarrow$ \\
\hline LIC12331 (LA1416) & mgsA & -1.72 & methylglyoxal synthase & - & - \\
\hline LIC12733 (LA0909) & & -1.58 & adolase & - & $\downarrow$ \\
\hline \multicolumn{6}{|l|}{ LIC12233 (LA1532) } \\
\hline $\begin{array}{l}\text { - amino acid transport and metabolism } \\
\text { (E) }\end{array}$ & & -2.17 & dioxygenase superfamily protein & - & - \\
\hline LIC10069 (LA0076) & $g \ln K$ & -2.17 & nitrogen regulatory protein PII & - & - \\
\hline LIC10440 (LA3807) & $\operatorname{cs} d B$ & -1.60 & selenocysteine lyase & - & - \\
\hline LIC20204 (LB267) & sped & -1.54 & adenosylmethionine decarboxylase & - & - \\
\hline LIC20239 (LA-SPN3792) & $g l t B$ & -1.53 & glutamate synthase (NADH) & - & - \\
\hline LIC12694 (LA0956) & & -1.52 & lactoylglutathione or related lyase & - & - \\
\hline \multicolumn{6}{|l|}{ LIC10460 (LA3782) } \\
\hline $\begin{array}{l}\text { - nucleotide transport and metabolism } \\
\text { (F) }\end{array}$ & & -1.65 & purine-nucleoside phosphorylase & - & - \\
\hline LIC13399 (LA4248) & $a d k$ & -1.55 & adenylate kinase & - & - \\
\hline \multicolumn{6}{|l|}{ LIC12852 (LA0760) } \\
\hline $\begin{array}{l}\text { - coenzyme transport and metabolism } \\
\text { (H) }\end{array}$ & ubiG & -1.86 & 2-polyprenyl-3-methyl-5- & & \\
\hline LIC10737 (LA3436) & & & $\begin{array}{l}\text { hydroxy-6-metoxy-1,4- } \\
\text { benzoquinol methylase }\end{array}$ & - & - \\
\hline - lipid transport and metabolism (I) & ivd & -1.77 & & - & - \\
\hline LIC10363 (LA0414) & & & isovaleryl-CoA dehydrogenase & & \\
\hline - inorganic ion transport and metabolism & $a m t B$ & -3.10 & & - & - \\
\hline$(\mathrm{P})$ & $k d p A$ & -2.09 & ammonia permease & $\uparrow$ & - \\
\hline LIC10441 (LA3806) & & & potassium-transporting ATPase A & & \\
\hline LIC10990 (LA3112) & & & chain & & \\
\hline
\end{tabular}

${ }^{\mathrm{a}}$ Gene ID is based on predicted ORFs of whole-genome sequence of $L$. interrogans serovar Copenhageni. Gene ID of corresponding serovar Lai is in parenthesis. ORFs of unknown or poorly characterized function were excluded from this table.

${ }^{\mathrm{b}}$ Previous microarray data on the effect of overnight $37^{\circ} \mathrm{C}$ upshift [11] compared to growth at $30^{\circ} \mathrm{C}$.

'Previous microarray data on the effect of osmolarity upshift [13] compared to EMJH medium.

$\mathrm{d} \uparrow$ represents up-regulation of gene expression and $\downarrow$ represents down-regulation of gene expression.

utilize hemoglobin $(\mathrm{Hb})$ as the sole iron source [72]. In contrast, the growth of this mutant in EMJH medium, which is supplemented with $\mathrm{FeSO}_{4}$, was not impaired. Therefore, up-regulation of leptospiral hemO is likely to be necessary for iron acquisition during iron limitation conditions in serum. Indeed, $\mathrm{HemO}$ is required for disease pathogenesis in hamsters [73]. In addition, realtime RT-PCR was performed on putative genes involved in iron metabolism to examine gene regulation in response to different iron sources, namely $\mathrm{Hb}$ and $\mathrm{Fe}^{2+}$. The results showed that hem $O$ was up-regulated when leptospires were grown in medium supplemented with $\mathrm{Hb}$. Genes encoding TonB-dependent receptors (LIC12898/LA0706, LIC12374/LA1356, LIC11345/ LA2641, and LIC10714/LB3468), Fur-like proteins (LIC11006/LA3094, LIC12034/LA1857, LIC11158/ LA2887, and LIC20147/LB183), and hemin-binding protein (HbpA encoded by LIC20151/LB191), were not or weakly differentially expressed in response to $\mathrm{Hb}$ [72].
Similarly, except for hem $O$, expression of other genes involved in iron acquisition systems [70] was not significantly affected by serum in our study. Notably, one of 12 putative TonB-dependent receptors (LIC11694) [70], was 1.8-fold up-regulated in response to serum (adjusted $P$ value $=0.02$ ). It is probable that the expression of genes involved in iron uptake and transport depends on available iron sources in the environment during infection.

Two genes encoding proteins predicted to be involved in nitrogen assimilation, $a m t B$ (LIC10441), encoding ammonia permease, and $g \ln K$ (LIC10440), encoding nitrogen regulatory protein II (PII), were down-regulated 3.1-fold (the most strongly down-regulated gene in our study) and 2.17-fold, respectively. In bacteria, $g \ln K$ and $a m t B$ are conserved and co-transcribed as an operon [73]. PII serves as a signal transduction protein for sensing external ammonium availability and nitrogen status of the cell while ammonia permease acts as a channel 
for ammonium transport [74]. Ammonium is an important source of nitrogen for biosynthesis of amino acids, nucleotides, and biological amines. Expression of the glnKamtB operon is generally induced during growth under limited ammonium conditions [73]. Therefore, ammonia appears to be available in sufficient concentrations in serum in comparison to EMJH medium, resulting in down-regulation of the $g \operatorname{lnKamtB}$ operon.

Beta-oxidation of long-chain fatty acids serves as the major mechanism for energy and carbon acquisition by Leptospira $[33,34,75,76]$. The gene encoding a predicted enoyl-CoA hydratase (LIC12629), which catalyzes the second step of fatty acid oxidation [77], was up-regulated in response to serum, but the expression of other genes in the fatty acid oxidation pathway was not altered. However, LIC12629 is located distantly from other genes in the same pathway and is clearly regulated independently. Leptospiral genes predicted to be involved in the tricarboxylic acid (TCA) cycle, namely gltA (LIC12829), encoding citrate synthase and $s d h A$ (LIC12002), encoding a flavoprotein subunit of succinate dehydrogenase, and aceF (LIC12476), encoding a subunit of the pyruvate dehydrogenase complex were down-regulated. The results suggest that acetylCoA derived from fatty acid oxidation was less likely to feed into the TCA cycle. In addition, it was previously shown that transcription of several enzymes in the TCA cycle is iron-dependent or regulated by Fur [78]. It is possible that expression of these genes was repressed when leptospires encountered the low-iron milieu in serum. Similar findings were observed in Yersinia pseudotuberculosis grown in plasma, resulting in down-regulation of several enzymes of the TCA cycle [79].

The transition of Leptospira to serum resulted in upregulation of pyrD (LIC13433), predicted to encode a dihydroorotate dehydrogenase which catalyzes the fourth step in the de novo pyrimidine nucleotide biosynthetic pathway [80], possibly due to limited availability of pyrimidine in serum. This finding is consistent with previous reports showing that the scarcity of nucleotide precursors is the key limitation of bacterial growth in blood [81]. Therefore, de novo nucleotide biosynthesis may be required for growth of leptospires in serum. However, enzymes involved in de novo biosynthesis of purine nucleotides were not induced in our study. Notably, down-regulation of one of the purine salvage enzymes (LIC13399, predicted to encode a purinenucleoside phosphorylase) was observed. It has been suggested that transcription of genes in purine and pyrimidine biosynthetic pathways is independently regulated $[80,81]$. In addition, it is possible that differential expression of genes involved in purine biosynthesis was transient and may not show steady-state expression ratios.
Therefore, these genes were not detected as differentially expressed. In addition, coaE (LIC13085) encoding dephospho-CoA kinase, which catalyzes the final step in coenzyme A biosynthesis [82], was up-regulated in response to serum, consistent with the use of coenzyme A as a key cofactor during serum exposure.

The $k d p F A B C$ operon is typically induced under conditions of severe $\mathrm{K}^{+}$limitation or osmotic upshift and repressed during growth in media of high external $\mathrm{K}^{+}$ concentration [83]. The putative $k d p A$ (LIC10990) encoding the A chain of potassium-transporting ATPase was down-regulated in response to serum. However, as the level of potassium in EMJH $(2.2 \mathrm{mM})$ is lower than in serum $(\sim 5.2 \mathrm{mM})$ this result is not surprising.

Two leptospiral genes predicted to encode fatty acid desaturases (LIC13053 [desA] and LIC20052) were upregulated in the presence of serum. The unsaturated bonds introduced into fatty acids by these enzymes have been reported to be essential for membrane lipid homeostasis to maintain the fluidity of biological membranes, especially in response to downward temperature shift $[84,85]$. The ability of Leptospira to modulate its membrane lipid using fatty acid desaturases may thus be important for survival in response to environmental stresses encountered in serum.

Bacterial genes of related functions, including enzymes of metabolic pathways, are frequently but not always co-transcribed as a single transcriptional unit. In our study, genes putatively organized in the same operons, such as hemO (LIC20148) and LIC20149, and $g \ln K$ and $a m t B$ genes, were similarly differentially regulated. However, some genes, such as pyrD (LIC13433), $k d p A$ (LIC10990), and $s d h A$ (LIC12002), did not have the same levels of expression as other genes within their putative operons. A possible explanation could be due to transcriptional polarity [86], where the level of expression of distal genes is less than that of promoter-proximal genes. In addition, the expression of the constituent genes in an operon may sometimes be discoordinated at the suboperonic level by the presence of internal promoters, differential translational efficiency, or differential instability of regions of a polycistronic mRNA [87]. This allows a subset of the operon to be separately transcribed as an internal mini-operon in response to different signals. Finally, most predicted operons have not been verified experimentally, and the genes therein can in reality be transcribed independently. The definite answer to these various possibilities must await further investigation.

\section{Complement resistance and other virulence determinants}

Complement-resistant L. interrogans serovar Copenhageni was used in our study. Previous reports demonstrated that complement resistance of pathogenic 
Leptospira is related to factor H-binding, degradation of $\mathrm{C} 3 \mathrm{~b}$ and $\mathrm{C} 3$ convertase, and inhibition of membraneattack complex deposition [24,38]. Factor $\mathrm{H}$ acts as a complement regulator by binding to $\mathrm{C} 3 \mathrm{~b}$ and displacing $\mathrm{Bb}$ from $\mathrm{C} 3$ convertases, thereby promoting factor $\mathrm{I}$ in cleaving C3b into its inactive form, $\mathrm{iC} 3 \mathrm{~b}$ [88]. Binding to factor $\mathrm{H}$ is one of the mechanisms that bacteria utilize to evade complement killing [89]. LfhA (also known as LenA) and LenB of L. interrogans were previously shown to interact with factor $H[24,61]$. However, in our study, genes encoding these factor H-binding proteins were not significantly up-regulated.

With the exception of LigB, other known or potential virulence determinants that play a role in motility, chemotaxis, colonization or adhesion were not found to be up-regulated after exposure to serum. These include extracellular matrix binding proteins, enzymes capable of host cell membrane degradation such as sphingomyelinase, phosphatase, and hemolysin, as well as surface proteins previously shown to be expressed in vivo, including OmpL1, LipL41, LipL32, LipL21, LipL46, Loa22, and Lsa21, [17,19-23,25-27,33,34,90,91]. In addition, recent studies using genome-wide transposon mutagenesis of $L$. interrogans revealed novel virulence genes, LA1641 (or LIC12143) and LA0615 (or LIC12967), which resulted in attenuation in hamsters when the genes were insertionally inactivated [92]. Neither gene was differentially expressed in our experiments.

While it is possible that some virulence-associated proteins may be expressed constitutively or regulated at the post-transcriptional level, transcription of some genes may also be influenced by the presence or absence of components in the EMJH medium. It is also possible that conditions different from those used in our study may be required to stimulate these genes, such as time period of serum exposure, growth phase of leptospires, cell density, mediators released from inflammatory cells, or microbe-host cell interactions. Microarray analyses are also limited in that unstable or short-lived transcripts cannot be accurately measured.

\section{Comparison with microarray data on effect of temperature and osmolarity changes}

We compared our results with previous microarray data on the effect of temperature and osmolarity changes on leptospiral gene expression $[11,13,15]$. Due to different criteria applied in these studies, we have re-analysed the previous microarray data using the same statistical criteria (at least 1.5 -fold ratio and adjusted $P$ value $<0.01$ ). The overnight $37^{\circ} \mathrm{C}$ upshift vs $30^{\circ} \mathrm{C}$ dataset [11] was the temperature condition used for comparison. Of the total 168 differentially expressed genes, expression of 36 of 55 (65.5\%) up-regulated genes and 94 of $113(83.2 \%)$ down-regulated genes was considered to be serum-specific, i.e. genes that were differentially regulated in response only to serum exposure but not to temperature and/or osmolarity shift [Additional files 1 and 2]. Most leptospiral genes in each general COG grouping that were significantly up-regulated (Figure 2A) or downregulated (Figure 2B) by serum were not affected by temperature or osmolarity. Hence, serum appeared to generate complex signals that were different from the single-stimulus signal of temperature and osmolarity changes. In the up-regulated group, 20\% (11 of 55 genes) were also induced in response to physiological osmolarity shift, whereas only $9.1 \%$ (5 of 55 genes) were up-regulated also in response to temperature shift (Table 4). In addition, 3 (2.7\%) and 14 (12.4\%) of 113 down-regulated genes were also repressed in response to temperature and osmolarity shifts, respectively (Table $4)$. In other words, the transcriptional profile in response to serum was more similar to that of the response to increased osmolarity rather than to temperature shift. This finding can be attributed to the fact that both the experimental and control samples were incubated at the same temperature and therefore, transcriptional differences due to temperature shift would be excluded. However, differences between our findings and those of previous microarray studies may also be due to variation of experimental conditions between studies, such as the incubation period and cell density.

Table 4 Number of leptospiral genes differentially expressed in response to serum compared with the effects of temperature and osmolarity shifts ${ }^{a}$

\begin{tabular}{|c|c|c|c|c|c|c|}
\hline \multirow[t]{2}{*}{ Serum effect } & \multicolumn{2}{|c|}{ Temperature effect } & \multicolumn{2}{|c|}{ Osmolarity effect } & \multicolumn{2}{|c|}{ Temperature and osmolarity effect } \\
\hline & Up-regulated & Down-regulated & Up-regulated & Down-regulated & Up-regulated & Down-regulated \\
\hline$\overline{\text { Up-regulated }\left(\%^{\mathrm{b}}\right)}$ & $5(9.1)$ & $2(3.6)$ & $11(20)$ & $0(0)$ & $3(5.6)$ & $0(0)$ \\
\hline Down-regulated $\left(\%^{\mathrm{C}}\right)$ & $9(8)$ & $3(2.7)$ & $2(1.8)$ & $14(12.4)$ & $0(0)$ & $2(1.8)$ \\
\hline
\end{tabular}


A.

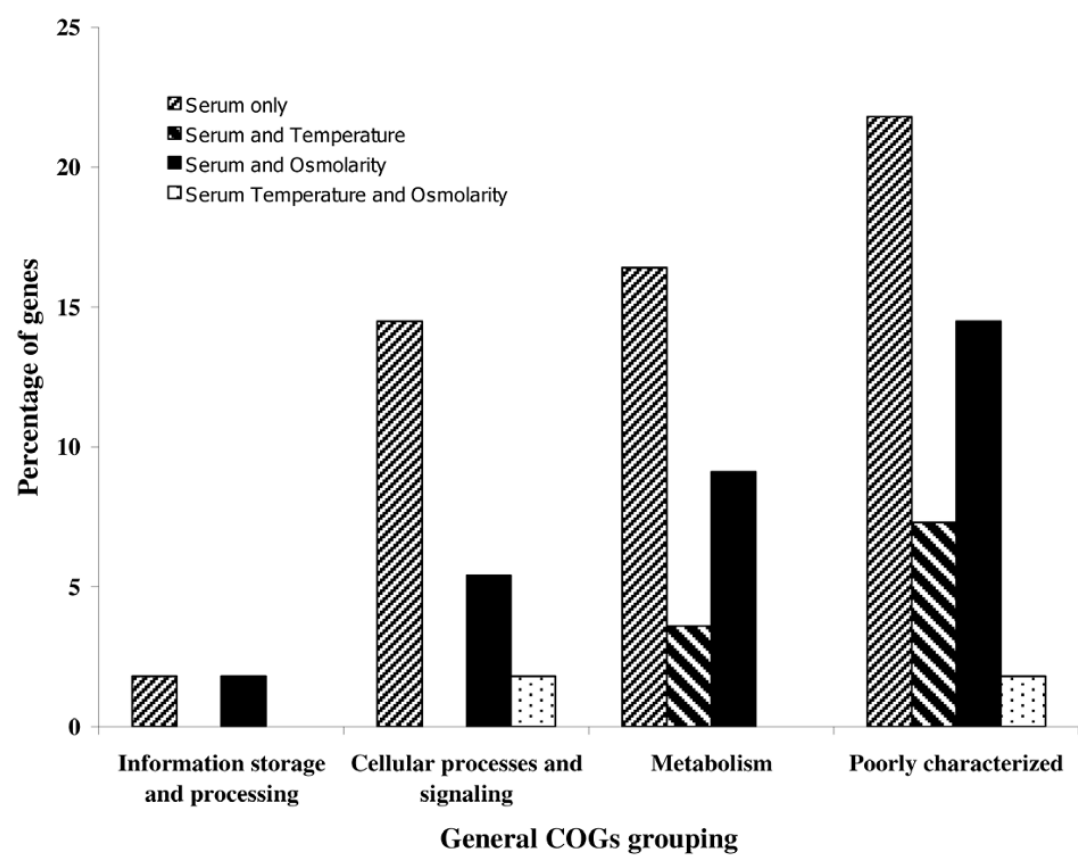

B.

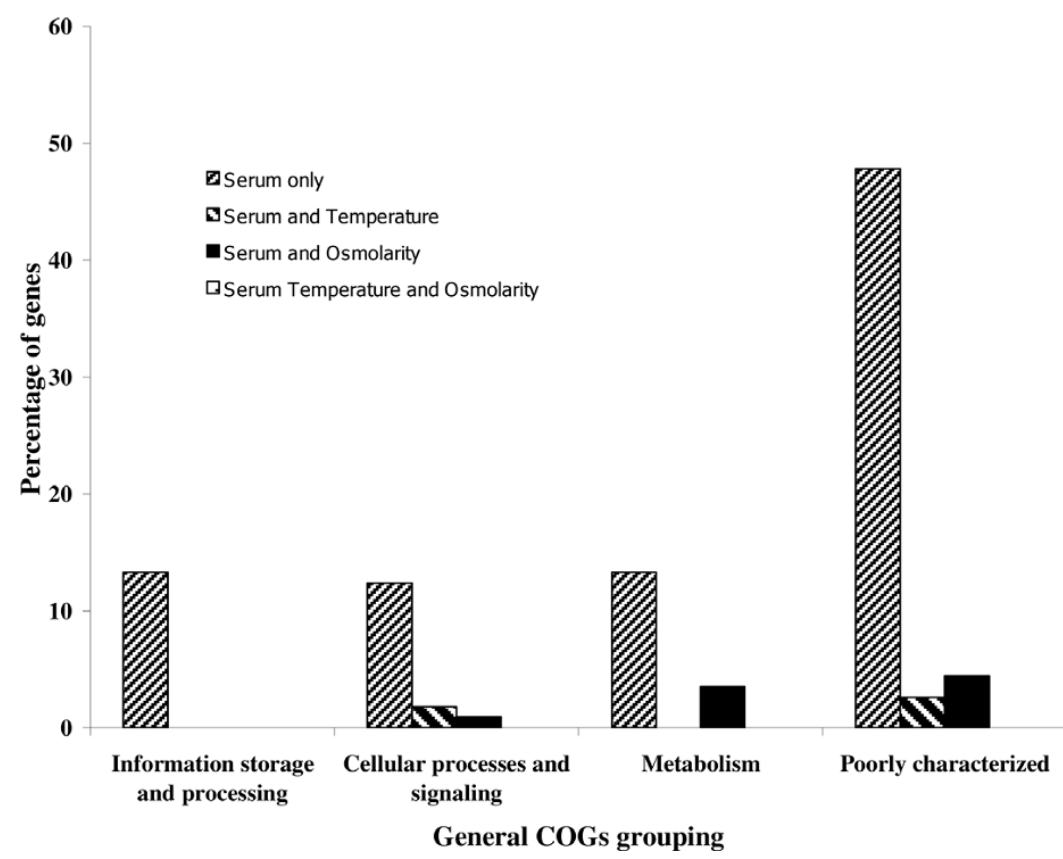

Figure 2 Percentage of up-regulated (A) and down-regulated (B) genes of $L$. interrogans serovar Copenhageni in response to serum that were differentially expressed due to the effect of: serum only, serum and temperature shift, serum and osmolarity shift, and all three conditions; in each general COG grouping. 
Interestingly, $\operatorname{lig} B$ was the only gene of known or predicted function that was up-regulated in response to all three conditions $[11,13,15,16]$. Therefore, this gene is most likely induced during early bloodstream infection upon exposure to serum and temperature and osmolarity shift. This finding correlates with previous studies showing that anti-LigB IgM was found in more than $95 \%$ of patients with acute leptospiral infection [93]. It is therefore intriguing that $\operatorname{lig} B$ is not essential for acute infection of hamsters or for rat kidney colonization [58]. Interestingly, no gene of known or predicted function was down-regulated by all three signals. In addition, expression of genes encoding proteins known to be temperature regulated, such as LipL36 [8] and Qlp42 [14], was not altered in our study, a finding consistent with previous work on the effect of temperature on these genes [11].

\section{Validation of microarray data by quantitative RT-PCR}

To validate the microarray data, 12 genes were selected for quantitative RT-PCR. Genes encoding flagella subunits, flaB and flaA2 did not show any transcriptional changes under different temperature or osmolarity conditions and were used for normalization of RT-PCR data in those studies $[11,13]$. Likewise, flaB transcription was not altered by the presence of serum and therefore, flaB was used for normalization of RT-PCR data in this study. The correlation coefficient $\left(R^{2}\right)$ between expression measured by microarray and real-time quantitative PCR was 0.812 [Additional file 3].

\section{Conclusions}

We studied global changes at the transcriptional level of $L$. interrogans serovar Copenhageni in response to serum, thus mimicking the early bacteremic phase of infection. Out of a total of 3,711 ORFs, 168 genes (4.5\%) were found to be differentially expressed. To adapt to stress signals in serum, several genes involved in transcriptional regulation, translational process, signal transduction systems, cell or membrane biogenesis, enzymes in various metabolic pathways, and unknown genes were differentially expressed. Serum appeared to be a unique stimulus for leptospires, resulting in a distinct pattern of gene expression compared with genes found to be regulated by only temperature or osmolarity shifts. The only gene of known or predicted function induced by all three conditions was ligB. However, many genes previously reported to be virulence associated were not up-regulated in the presence of serum. Expression of these genes may require additional signals that were absent from our study. Alternatively, these genes may be expressed transiently in particular host niches, expressed constitutively or the proteins may be regulated at the translational level. In addition, microarray analyses are also limited in that transcripts which are unstable or have a short half-life are unlikely to be measured accurately. However, our results serve to advance our understanding of genes which may be important in pathogenesis. Genes of unknown function are over represented in the set of genes unique to pathogenic Leptospira spp. [45], consistent with the notion that Leptospira possesses unique virulence factors. Accordingly, such genes of unknown function that are differentially regulated upon serum exposure warrant further investigation to gain a better insight into their roles in the pathogenesis of leptospirosis.

\section{Methods}

\section{Bacterial growth and conditions}

Pathogenic L. interrogans serovar Copenhageni strain L533, and non-pathogenic L. biflexa serovar Patoc strain L41 were grown in EMJH broth medium at $30^{\circ} \mathrm{C}$ under aerobic conditions. Leptospires were grown to exponential phase at an approximate density of 5-8 $\times$ $10^{8} \mathrm{cells} / \mathrm{ml}$ before harvesting by centrifugation at 8000 $\times \mathrm{g}$.

\section{Complement and heat-inactivated sera}

Normal guinea pig serum (NGS) (Sigma, St Louis, MO) was obtained lyophilized and stored at $-80^{\circ} \mathrm{C}$ until use. Serum was reconstituted in 1 or $5 \mathrm{ml}$ of sterile ice-cold deionized water according to the manufacturer's instructions. To maintain consistency, the same batch of serum was used throughout. Heat-inactivated serum (HIS) was obtained by incubating NGS at $56^{\circ} \mathrm{C}$ for $30 \mathrm{~min}$. Sera were freshly prepared before use or stored at $-80^{\circ} \mathrm{C}$ until use. Serum was prewarmed at $37^{\circ} \mathrm{C}$ for 30 min before incubating with leptospires.

\section{Serum bactericidal assay}

Serum bactericidal assays were performed as described previously with minor modification [38]. Pathogenic leptospires were grown to exponential phase and diluted in liquid EMJH medium to a density of $2 \times 10^{8} \mathrm{cells} / \mathrm{ml}$ before use. $1 \times 10^{7}$ bacteria were incubated with $50 \%$ NGS in a final volume of $100 \mu \mathrm{l}$ at $37^{\circ} \mathrm{C}$ for up to $2 \mathrm{~h}$. HIS was used as a control. Samples were taken at different time points and viable spirochetes were enumerated by dark-field microscopy using a Petroff-Hausser counting chamber. The percentage of viable leptospires was calculated by comparison with those incubated with $50 \%$ HIS which were considered as $100 \%$ viability. The assay was performed in triplicate. The non-pathogenic, complement-sensitive L. biflexa serovar Patoc was used in parallel under the same conditions as a control for serum killing. 


\section{Microarray construction}

Microarrays were constructed based on a revised annotation of the whole genome sequence of $L$. interrogans serovar Lai strain 56601, with the addition of 45 ORFs unique to L. interrogans serovar Copenhageni strain Fiocruz L1-130 as described previously [11].

\section{Serum exposure and RNA isolation}

One hundred $\mathrm{ml}$ cultures of L. interrogans serovar Copenhageni strain L533 were divided equally between 2 tubes and harvested by centrifugation at $8,000 \times \mathrm{g}$ for $20 \mathrm{~min}$ at room temperature. The cell pellet in each tube was resuspended in $5 \mathrm{ml}$ of either prewarmed EMJH or prewarmed 50\% NGS in EMJH. After incubation at $37^{\circ} \mathrm{C}$ for $30 \mathrm{~min}, 0.5 \mathrm{ml}$ of ice-cold killing buffer (50 mM Tris- $\mathrm{HCl}, \mathrm{pH} 7.5,15 \mathrm{mg} / \mathrm{ml}$ sodium azide, 0.6 $\mathrm{mg} / \mathrm{ml}$ chloramphenicol) was immediately added to each tube before chilling on ice for $5 \mathrm{~min}$. The NGS- and $\mathrm{EMJH}$-treated cells were harvested by centrifugation at $4^{\circ} \mathrm{C}$ for $15 \mathrm{~min}$ and RNA isolated as described previously [11]. The concentration and purity of RNA were measured with a Nanodrop-1000 spectrophotometer (ThermoScientific, Wilmington, DE) and RNA integrity was determined by agarose gel electrophoresis. The lack of DNA contamination in the RNA sample was checked by PCR using $0.5 \mu \mathrm{g}$ of RNA and primers for flaB [Additional file 4].

\section{Preparation of labeled cDNA probes and microarray hybridization}

Each labeled cDNA probe was derived from $2.5 \mu \mathrm{g}$ of total RNA using the 3DNA Array 900 MPX expression array detection kit (Genisphere, Hatfield, PA) according to the manufacturer's instructions. The comparison between NGS-treated and EMJH-grown samples had 3 biological replicates with a dye swap for each replicate, resulting in 6 arrays. Hybridization was carried out using the 3DNA Array 900 MPX expression array detection kit as per the manufacturer's instructions and as described previously [11].

\section{Analysis of microarray images and statistical criteria}

After hybridization, the microarray slides were immediately scanned with a GMS 418 array scanner (Genetic Microsystems, Woburn, MA). The fluorescent intensities of spots from the $\mathrm{Cy} 3$ and $\mathrm{Cy} 5$ images were quantitated with ImaGene version 5.1 (Biodiscovery, El Segundo, CA). Spots with poor quality were flagged for elimination from subsequent analysis steps. The web-based program Bioarray Software Environment (BASE) was used for data analysis as described previously $[11,13]$. Briefly, spot-specific median background intensities were subtracted from spot-specific median signals. Only spots with a corrected intensity of greater than 250 were further analyzed. Data normalization for each array was performed independently using the global median ratio, which scales the intensities such that the median of the ratio between $\mathrm{Cy} 3$ and Cy 5 channels was 1 and spots within 5\% of the lowest and the highest intensities were excluded. Print-tip loess normalization was applied to each array, followed by between-arrays normalization, which scales all replicate arrays such that they had the same median absolute deviation. Direct comparison of gene expression between NGS-treated and EMJH-grown samples was based on moderated $t$ test and associated $P$ values adjusted for multiple testing by controlling the false discovery rate. Differentially expressed genes were considered to be statistically significant if an absolute relative ratio was greater than 1.5 fold with an adjusted $P$ value of less than 0.01 . The data discussed in this publication have been deposited in NCBI's Gene Expression Omnibus (Edgar et $a l ., 2002)$ and are accessible through GEO Series accession number GSE17942 http://www.ncbi.nlm.nih.gov/ geo/query/acc.cgi?acc=GSE17942.

\section{Validation of microarray data by qRT-PCR}

Twelve differentially expressed genes with varying degrees of up- and down-regulation were selected from the microarray results for qRT-PCR. Primers for realtime RT-PCR were designed using Primer Express software (ABI, Foster City, CA) [Additional file 3]. Each RT reaction mixture contained $5 \mu \mathrm{g}$ of total RNA, $7.5 \mu \mathrm{g}$ of random hexamers, 300 units of Superscript III reverse transcriptase (Invitrogen), $1 \mathrm{mM}$ dNTP mix (1 mM each dATP, dGTP, dCTP, and dTTP), $10 \mathrm{mM}$ DTT, and 20 units rRNasin ${ }^{\circ}$ RNase inhibitor (Promega, Madison, WI). Samples were incubated at $42^{\circ} \mathrm{C}$ for $2.5 \mathrm{~h}$ then at $70^{\circ} \mathrm{C}$ for $15 \mathrm{~min}$. The synthesized cDNA was diluted $1 / 50$ to $1 / 100$ prior to use in real-time PCR. Real-time PCR reaction mixtures each contained $2.5 \mu \mathrm{L}$ of cDNA, gene-specific primers at a final concentration of $100 \mathrm{nM}$ each, and $10 \mu \mathrm{L}$ of SYBR Green PCR master mix (ABI) in a total volume of $20 \mu \mathrm{L}$. Real-time PCR was carried out using a Mastercycler ep realplex real-time PCR system (Eppendorf, Hamburg, Germany). Reactions were performed in triplicate. A standard curve for each gene was constructed using known concentrations of $L$. interrogans serovar Copenhageni genomic DNA. The gene encoding flagella subunit B, flaB, was used to normalize all data. Melting curve analysis confirmed that all PCRs amplified a single product.

\section{List of abbreviations}

EMJH medium: Ellinghausen-McCullough-Johnson-Harris medium; NGS: normal guinea pig serum; HIS: heatinactivated guinea pig serum; ORF: open reading frame; qRT-PCR: quantitative reverse transcription polymerase chain reaction. 
Additional file 1: Table S1. List of genes upregulated in serum, with an adjusted $P$ value of $<0.01$

Click here for file

[http://www.biomedcentral.com/content/supplementary/1471-2180-1031-S1.XLS ]

Additional file 2: Table S2. List of genes downregulated in serum, with an adjusted $P$ value of $<0.01$.

Click here for file

[http://www.biomedcentral.com/content/supplementary/1471-2180-1031-S2.XLS]

Additional file 3: Figure S1. Comparison of quantitative RT-PCR and microarray data for twelve genes with varying degrees of up- and downregulation selected at random.

Click here for file

[http://www.biomedcentral.com/content/supplementary/1471-2180-1031-S3.DOC ]

Additional file 4: Table S3. Sequences of primers used for PCR and for real-time qRT-PCR to confirm microarray data for some genes.

Click here for file

[http://www.biomedcentral.com/content/supplementary/1471-2180-1031-S4.DOC]

\section{Acknowledgements}

This work was supported by grants from the Australian Research Council and the National Health and Medical Research Council. KP was supported financially by the Faculty of Medicine, Chulalongkorn University, Thailand. KP also acknowledges with thanks the kind help from her colleagues at the Department of Microbiology, Faculty of Medicine, Chulalongkorn University, Thailand during her absence.

\section{Author details}

'Faculty of Medicine, Chulalongkorn University, Bangkok 10330, Thailand. ${ }^{2}$ ARC Centre of Excellence in Structural and Functional Microbial Genomics, Monash University, Clayton, Victoria 3800, Australia. ${ }^{3}$ Department of Microbiology, School of Biomedical Sciences, Monash University, Clayton, Victoria 3800, Australia.

\section{Authors' contributions}

KP performed the experimental work and statistical analyses under the supervision of $M L$ and $B A . M L$ and $B A$ were involved in microarray design and construction. KP wrote the manuscript with assistance of ML and BA. All authors have read and approved the content of this article.

Received: 16 June 2009

Accepted: 29 January 2010 Published: 29 January 2010

\section{References}

1. Bharti AR, Nally JE, Ricaldi JN, Matthias MA, Diaz MM, Lovett MA, Levett PN, Gilman RH, Willig MR, Gotuzzo E, Vinetz JM: Leptospirosis: a zoonotic disease of global importance. Lancet Infect Dis 2003, 3:757-771.

2. McBride AJ, Athanazio DA, Reis MG, Ko Al: Leptospirosis. Curr Opin Infect Dis 2005, 18:376-386.

3. Palaniappan RU, Ramanujam S, Chang YF: Leptospirosis: pathogenesis, immunity, and diagnosis. Curr Opin Infect Dis 2007, 20:284-292.

4. Brenner DJ, Kaufmann AF, Sulzer KR, Steigerwalt AG, Rogers FC, Weyant RS: Further determination of DNA relatedness between serogroups and serovars in the family Leptospiraceae with a proposal for Leptospira alexanderi sp. nov. and four new Leptospira genomospecies. Int I Syst Bacteriol 1999, 49:839-858.

5. Levett PN, Morey RE, Galloway RL, Steigerwalt AG: Leptospira broomii sp. nov., isolated from humans with leptospirosis. Int I Syst Evol Microbiol 2006, 56:671-673.

6. Levett PN: Sequence-based typing of leptospira: epidemiology in the genomic era. PLoS Negl Trop Dis 2007, 1:e120.

7. Trueba G, Zapata S, Madrid K, Cullen P, Haake D: Cell aggregation: a mechanism of pathogenic Leptospira to survive in fresh water. Int Microbiol 2004, 7:35-40.
8. Nally JE, Timoney JF, Stevenson B: Temperature-regulated protein synthesis by Leptospira interrogans. Infect Immun 2001, 69:400-404

9. Cullen PA, Cordwell SJ, Bulach DM, Haake DA, Adler B: Global analysis of outer membrane proteins from Leptospira interrogans serovar Lai. Infect Immun 2002, 70:2311-2318

10. Qin JH, Sheng YY, Zhang ZM, Shi YZ, He P, Hu BY, Yang Y, Liu SG, Zhao GP, Guo XK: Genome-wide transcriptional analysis of temperature shift in $L$. interrogans serovar lai strain 56601. BMC Microbiol 2006, 6:51.

11. Lo M, Bulach DM, Powell DR, Haake DA, Matsunaga J, Paustian ML, Zuerner RL, Adler B: Effects of temperature on gene expression patterns in Leptospira interrogans serovar Lai as assessed by whole-genome microarrays. Infect Immun 2006, 74:5848-5859.

12. Matsunaga J, Medeiros MA, Sanchez Y, Werneid KF, Ko Al: Osmotic regulation of expression of two extracellular matrix-binding proteins and a haemolysin of Leptospira interrogans : differential effects on LigA and Sph2 extracellular release. Microbiology 2007, 153:3390-3398.

13. Matsunaga J, Lo M, Bulach DM, Zuerner RL, Adler B, Haake DA: Response of Leptospira interrogans to physiologic osmolarity: relevance in signaling the environment-to-host transition. Infect Immun 2007, 75:2864-2874.

14. Nally JE, Artiushin S, Timoney JF: Molecular characterization of thermoinduced immunogenic proteins Q1p42 and Hsp15 of Leptospira interrogans. Infect Immun 2001, 69:7616-7624.

15. Matsunaga J, Sanchez $Y, X u X$, Haake DA: Osmolarity, a key environmental signal controlling expression of leptospiral proteins LigA and LigB and the extracellular release of LigA. Infect Immun 2005, 73:70-78.

16. Choy HA, Kelley MM, Chen TL, Moller AK, Matsunaga J, Haake DA Physiological osmotic induction of Leptospira interrogans adhesion: LigA and LigB bind extracellular matrix proteins and fibrinogen. Infect Immun 2007, 75:2441-2450.

17. Atzingen MV, Barbosa AS, De Brito T, Vasconcellos SA, de Morais ZM, Lima DM, Abreu PA, Nascimento AL: Lsa21, a novel leptospiral protein binding adhesive matrix molecules and present during human infection. BMC Microbiol 2008, 8:70.

18. Haake DA, Martinich C, Summers TA, Shang ES, Pruetz JD, McCoy AM, Mazel MK, Bolin CA: Characterization of leptospiral outer membrane lipoprotein LipL36: downregulation associated with late-log-phase growth and mammalian infection. Infect Immun 1998, 66:1579-1587.

19. Barnett JK, Barnett D, Bolin CA, Summers TA, Wagar EA, Cheville NF, Hartskeerl RA, Haake DA: Expression and distribution of leptospiral outer membrane components during renal infection of hamsters. Infect Immun 1999, 67:853-861.

20. Guerreiro H, Croda J, Flannery B, Mazel M, Matsunaga J, Galvao Reis M, Levett PN, Ko Al, Haake DA: Leptospiral proteins recognized during the humoral immune response to leptospirosis in humans. Infect Immun 2001, 69:4958-4968.

21. Haake DA, Chao G, Zuerner RL, Barnett JK, Barnett D, Mazel M, Matsunaga J, Levett PN, Bolin CA: The leptospiral major outer membrane protein LipL32 is a lipoprotein expressed during mammalian infection. Infect Immun 2000, 68:2276-2285.

22. Cullen PA, Haake DA, Bulach DM, Zuerner RL, Adler B: LipL21 is a novel surface-exposed lipoprotein of pathogenic Leptospira species. Infect Immun 2003, 71:2414-2421.

23. Matsunaga J, Werneid K, Zuerner RL, Frank A, Haake DA: LipL 46 is a novel surface-exposed lipoprotein expressed during leptospiral dissemination in the mammalian host. Microbiology 2006, 152:3777-3786

24. Verma A, Hellwage J, Artiushin S, Zipfel PF, Kraiczy P, Timoney JF, Stevenson B: LfhA, a novel factor H-binding protein of Leptospira interrogans. Infect Immun 2006, 74:2659-2666.

25. Asuthkar S, Velineni S, Stadlmann J, Altmann F, Sritharan M: Expression and characterization of an iron-regulated hemin-binding protein, $\mathrm{HbpA}$, from Leptospira interrogans serovar Lai. Infect Immun 2007, 75:4582-4591.

26. Nally JE, Whitelegge JP, Bassilian S, Blanco DR, Lovett MA: Characterization of the outer membrane proteome of Leptospira interrogans expressed during acute lethal infection. Infect Immun 2007, 75:766-773.

27. Ristow $P$, Bourhy $P$, da Cruz McBride FW, Figueira CP, Huerre $M$, Ave $P$, Girons IS, Ko Al, Picardeau M: The OmpA-like protein Loa22 is essential for leptospiral virulence. PLoS Pathog 2007, 3:e97.

28. Schoolnik GK: Microarray analysis of bacterial pathogenicity. Adv Microb Physiol 2002, 46:1-45. 
29. Dharmadi Y, Gonzalez R: DNA microarrays: experimental issues, data analysis, and application to bacterial systems. Biotechnol Prog 2004, 20:1309-1324

30. Hossain H, Tchatalbachev S, Chakraborty T: Host gene expression profiling in pathogen-host interactions. Curr Opin Immunol 2006, 18:422-429.

31. Burrack LS, Higgins DE: Genomic approaches to understanding bacterial virulence. Curr Opin Microbiol 2007, 10:4-9.

32. Waddell SJ, Butcher PD, Stoker NG: RNA profiling in host-pathogen interactions. Curr Opin Microbiol 2007, 10:297-302.

33. Ren $S X, F u$ G, Jiang XG, Zeng $R$, Miao $Y G$, Xu H, Zhang $Y X$, Xiong $H, L u ~ G$, $L u L F$, et al: Unique physiological and pathogenic features of Leptospira interrogans revealed by whole-genome sequencing. Nature 2003, 422:888-893.

34. Nascimento AL, Ko Al, Martins EA, Monteiro-Vitorello CB, Ho PL, Haake DA, Verjovski-Almeida S, Hartskeerl RA, Marques MV, Oliveira MC, et al: Comparative genomics of two Leptospira interrogans serovars reveals novel insights into physiology and pathogenesis. J Bacteriol 2004, 186:2164-2172.

35. Johnson RC, Harris VG: Antileptospiral activity of serum. II. Leptospiral virulence factor. J Bacterio/ 1967, 93:513-519.

36. Stalheim $\mathrm{OH}$ : Virulent and avirulent leptospires: biochemical activities and survival in blood. Am J Vet Res 1971, 32:843-849.

37. Cinco M, Banfi E: Activation of complement by leptospires and its bactericidal activity. Zentralbl Bakteriol Mikrobiol Hyg [A] 1983, 254:261-265.

38. Meri T, Murgia R, Stefanel P, Meri S, Cinco M: Regulation of complement activation at the C3-level by serum resistant leptospires. Microb Pathog 2005, 39:139-147.

39. Alves VA, Gayotto LC, De Brito T, Santos RT, Wakamatsu A, Vianna MR, Sakata EE: Leptospiral antigens in the liver of experimentally infected guinea pig and their relation to the morphogenesis of liver damage. Exp Toxicol Pathol 1992, 44:425-434.

40. Nally JE, Chantranuwat C, Wu XY, Fishbein MC, Pereira MM, Da Silva JJ, Blanco DR, Lovett MA: Alveolar septal deposition of immunoglobulin and complement parallels pulmonary hemorrhage in a guinea pig model of severe pulmonary leptospirosis. Am J Pathol 2004, 164:1115-1127.

41. Haake DA, Walker EM, Blanco DR, Bolin CA, Miller MN, Lovett MA: Changes in the surface of Leptospira interrogans serovar grippotyphosa during in vitro cultivation. Infect Immun 1991, 59:1131-1140.

42. Mosavi LK, Cammett TJ, Desrosiers DC, Peng ZY: The ankyrin repeat as molecular architecture for protein recognition. Protein Sci 2004, 13:1435-1448

43. Cho NH, Kim JM, Kwon EK, Kim SY, Han SH, Chu H, Lee JH, Choi MS, Kim IS: Molecular characterization of a group of proteins containing ankyrin repeats in Orientia tsutsugamushi. Ann N Y Acad Sci 2005, 1063:100-101.

44. Li J, Mahajan A, Tsai MD: Ankyrin repeat: a unique motif mediating protein-protein interactions. Biochemistry 2006, 45:15168-15178.

45. Picardeau M, Bulach DM, Bouchier C, Zuerner RL, Zidane N, Wilson PJ, Creno S, Kuczek ES, Bommezzadri S, Davis JC, et al: Genome sequence of the saprophyte Leptospira biflexa provides insights into the evolution of Leptospira and the pathogenesis of leptospirosis. PLOS ONE 2008, 3:e1607.

46. Gury J, Barthelmebs L, Tran NP, Divies C, Cavin JF: Cloning, deletion, and characterization of PadR, the transcriptional repressor of the phenolic acid decarboxylase-encoding padA gene of Lactobacillus plantarum. Appl Environ Microbiol 2004, 70:2146-2153.

47. Licandro-Seraut H, Gury J, Tran NP, Barthelmebs L, Cavin JF: Kinetics and intensity of the expression of genes involved in the stress response tightly induced by phenolic acids in Lactobacillus plantarum. J Mol Microbiol Biotechnol 2008, 14:41-47.

48. Orihuela CJ, Radin JN, Sublett JE, Gao G, Kaushal D, Tuomanen El: Microarray analysis of pneumococcal gene expression during invasive disease. Infect Immun 2004, 72:5582-5596.

49. Reid AN, Pandey R, Palyada K, Naikare H, Stintzi A: Identification of Campylobacter jejuni genes involved in the response to acidic $\mathrm{pH}$ and stomach transit. Appl Environ Microbiol 2008, 74:1583-1597.

50. Bore E, Langsrud S, Langsrud O, Rode TM, Holck A: Acid-shock responses in Staphylococcus aureus investigated by global gene expression analysis. Microbiology 2007, 153:2289-2303.

51. Wen Y, Marcus EA, Matrubutham U, Gleeson MA, Scott DR, Sachs G: Acidadaptive genes of Helicobacter pylori. Infect Immun 2003, 71:5921-5939.

52. Hayes ET, Wilks JC, Sanfilippo P, Yohannes E, Tate DP, Jones BD, Radmacher MD, BonDurant SS, Slonczewski JL: Oxygen limitation modulates $\mathrm{pH}$ regulation of catabolism and hydrogenases, multidrug transporters, and envelope composition in Escherichia coli K-12. BMC Microbiol 2006, 6:89.

53. Gyaneshwar P, Paliy O, McAuliffe J, Popham DL, Jordan MI, Kustu S: Sulfur and nitrogen limitation in Escherichia coli K-12: specific homeostatic responses. J Bacteriol 2005, 187:1074-1090.

54. Louvel H, Betton JM, Picardeau M: Heme rescues a two-component system Leptospira biflexa mutant. BMC Microbiol 2008, 8:25.

55. Campbell EA, Westblade LF, Darst SA: Regulation of bacterial RNA polymerase sigma factor activity: a structural perspective. Curr Opin Microbiol 2008, 11:121-127.

56. Lin YP, Chang YF: A domain of the Leptospira LigB contributes to high affinity binding of fibronectin. Biochem Biophys Res Commun 2007, 362:443-448.

57. Lin YP, Chang YF: The C-terminal variable domain of LigB from Leptospira mediates binding to fibronectin. J Vet Sci 2008, 9:133-144.

58. Lin YP, Raman R, Sharma Y, Chang YF: Calcium binds to leptospiral immunoglobulin-like protein, LigB, and modulates fibronectin binding. J Biol Chem 2008, 283:25140-25149.

59. Croda J, Figueira CP, Wunder EA Jr, Santos CS, Reis MG, Ko Al, Picardeau M: Targeted mutagenesis in pathogenic Leptospira species: Disruption of the $\operatorname{lig} B$ gene does not affect virulence in animal models of leptospirosis. Infect Immun 2008, 76:5826-5833.

60. Merien F, Truccolo J, Baranton G, Perolat P: Identification of a $36-k D a$ fibronectin-binding protein expressed by a virulent variant of Leptospira interrogans serovar icterohaemorrhagiae. FEMS Microbiol Lett 2000 185:17-22.

61. Barbosa AS, Abreu PA, Neves FO, Atzingen MV, Watanabe MM, Vieira ML, Morais ZM, Vasconcellos SA, Nascimento AL: A newly identified leptospiral adhesin mediates attachment to laminin. Infect Immun 2006, 74:6356-6364.

62. Stevenson B, Choy HA, Pinne M, Rotondi ML, Miller MC, Demoll E, Kraiczy P, Cooley $A E$, Creamer TP, Suchard MA, et al: Leptospira interrogans endostatin-like outer membrane proteins bind host fibronectin, laminin and regulators of complement. PLOS ONE 2007, 2:e1188.

63. Hoke DE, Egan S, Cullen PA, Adler B: LipL32 is an extracellular matrixinteracting protein of Leptospira spp. and Pseudoalteromonas tunicata. Infect Immun 2008, 76:2063-2069.

64. Buetow L, Smith TK, Dawson A, Fyffe S, Hunter WN: Structure and reactivity of $L p x D$, the $\mathrm{N}$-acyltransferase of lipid A biosynthesis. Proc Natl Acad Sci USA 2007, 104:4321-4326.

65. Raetz CR, Reynolds CM, Trent MS, Bishop RE: Lipid A modification systems in gram-negative bacteria. Annu Rev Biochem 2007, 76:295-329.

66. Kim N, Marcus EA, Wen Y, Weeks DL, Scott DR, Jung HC, Song IS, Sachs G: Genes of Helicobacter pylori regulated by attachment to AGS cells. Infect Immun 2004, 72:2358-2368.

67. Gibert I, Llagostera M, Barbe J: Regulation of ubiG gene expression in Escherichia coli. J Bacteriol 1988, 170:1346-1349.

68. Soballe B, Poole RK: Ubiquinone limits oxidative stress in Escherichia coli. Microbiology 2000, 146:787-796.

69. Poole LB: Bacterial Peroxiredoxins. Signal Transduction by Reactive Oxygen and Nitrogen Species: Pathways and Chemical Principles Dordrecht: Springer NetherlandsHenry Jay Forman JF, Martine Torres 2004, 80-101.

70. Louvel H, Bommezzadri S, Zidane N, Boursaux-Eude C, Creno S, Magnier A Rouy Z, Medigue C, Saint Girons I, Bouchier C, Picardeau M: Comparative and functional genomic analyses of iron transport and regulation in Leptospira spp. J Bacteriol 2006, 188:7893-7904.

71. Frankenberg-Dinkel N: Bacterial heme oxygenases. Antioxid Redox Signal 2004, 6:825-834.

72. Murray GL, Ellis KM, Lo M, Adler B: Leptospira interrogans requires a functional heme oxygenase to scavenge iron from hemoglobin. Microbes Infect 2008, 10:791-797.

73. Murray GL, Srikram A, Henry R, Puapairoj A, Sermswan RW, Adler B: Leptospira interrogans requires heme oxygenase for disease pathogenesis. Microbes Infect 2009, 11:311-314.

74. Thomas G, Coutts G, Merrick M: The glnKamtB operon. A conserved gene pair in prokaryotes. Trends Genet 2000, 16:11-14.

75. Javelle A, Merrick M: Complex formation between AmtB and GlnK: an ancestral role in prokaryotic nitrogen control. Biochem Soc Trans 2005, 33:170-172. 
76. Henneberry RC, Cox CD: Beta-oxidation of fatty acids by Leptospira. Can J Microbiol 1970, 16:41-45.

77. Khisamov GZ, Morozova NK: Fatty acids as resource of carbon for leptospirae. J Hyg Epidemiol Microbiol Immunol 1988, 32:87-93.

78. Pawar S, Schulz H: The structure of the multienzyme complex of fatty acid oxidation from Escherichia coli. J Biol Chem 1981, 256:3894-3899.

79. Zhang Z, Gosset G, Barabote R, Gonzalez CS, Cuevas WA, Saier MH Jr: Functional interactions between the carbon and iron utilization regulators, Crp and Fur, in Escherichia coli. J Bacteriol 2005, 187:980-990.

80. Rosso ML, Chauvaux S, Dessein R, Laurans C, Frangeul L, Lacroix C, Schiavo A, Dillies MA, Foulon J, Coppee JY, et al: Growth of Yersinia pseudotuberculosis in human plasma: impacts on virulence and metabolic gene expression. BMC Microbiol 2008, 8:211.

81. Turnbough CL Jr, Switzer RL: Regulation of pyrimidine biosynthetic gene expression in bacteria: repression without repressors. Microbiol Mol Biol Rev 2008, 72:266-300.

82. Samant S, Lee H, Ghassemi M, Chen J, Cook JL, Mankin AS, Neyfakh AA: Nucleotide biosynthesis is critical for growth of bacteria in human blood. PLoS Pathog 2008, 4:e37.

83. Mishra P, Park PK, Drueckhammer DG: Identification of yacE (coaE) as the structural gene for dephosphocoenzyme A kinase in Escherichia coli K12. J Bacteriol 2001, 183:2774-2778.

84. Ballal A, Basu B, Apte SK: The Kdp-ATPase system and its regulation. J Biosci 2007, 32:559-568.

85. Los DA, Murata N: Structure and expression of fatty acid desaturases. Biochim Biophys Acta 1998, 1394:3-15.

86. Zhang YM, Rock CO: Membrane lipid homeostasis in bacteria. Nat Rev Microbiol 2008, 6:222-233.

87. de Smit MH, Verlaan PW, van Duin J, Pleij CW: In vivo dynamics of intracistronic transcriptional polarity. J Mol Biol 2009, 385:733-747.

88. Adhya S: Suboperonic regulatory signals. SCi STKE 2003, 2003:pe22

89. Zipfel PF, Jokiranta TS, Hellwage J, Koistinen V, Meri S: The factor H protein family. Immunopharmacology 1999, 42:53-60.

90. Rautemaa R, Meri S: Complement-resistance mechanisms of bacteria. Microbes Infect 1999, 1:785-794.

91. Lee SH, Kim S, Park SC, Kim MJ: Cytotoxic activities of Leptospira interrogans hemolysin $\mathrm{SphH}$ as a pore-forming protein on mammalian cells. Infect Immun 2002, 70:315-322.

92. Murray GL, Morel V, Cerqueira GM, Croda J, Srikram A, Henry R, Ko Al, Dellagostin OA, Bulach DM, Sermswan R, et al: Genome-wide transposon mutagenesis in pathogenic Leptospira spp. Infect Immun 2009, 77:810-816.

93. Matsunaga J, Barocchi MA, Croda J, Young TA, Sanchez Y, Siqueira I, Bolin CA, Reis MG, Riley LW, Haake DA, Ko Al: Pathogenic Leptospira species express surface-exposed proteins belonging to the bacterial immunoglobulin superfamily. Mol Microbiol 2003, 49:929-945.

doi:10.1186/1471-2180-10-31

Cite this article as: Patarakul et al:: Global transcriptomic response of Leptospira interrogans serovar Copenhageni upon exposure to serum. BMC Microbiology 2010 10:31.

\section{Submit your next manuscript to BioMed Central and take full advantage of:}

- Convenient online submission

- Thorough peer review

- No space constraints or color figure charges

- Immediate publication on acceptance

- Inclusion in PubMed, CAS, Scopus and Google Scholar

- Research which is freely available for redistribution

Submit your manuscript at www.biomedcentral.com/submit
Biomed Central 